Thorax (1975), 30, 528.

\title{
Fascia lata valves: a clinicopathological study
}

\author{
E. G. J . O L S E N, N. A L - J A N A B I, C. S. S A L A M A Ó, \\ a n d D. N.R O S S \\ Department of Morbid Anatomy and Histopathology, Homograft Department and Department \\ of Surgery, National Heart Hospital and Cardiothoracic Institute, University of London
}

\begin{abstract}
Olsen, E. G. J., Al-Janabi, N., Salamaó, C. S., and Ross, D. N. (1975). Thorax, 30, 528-534. Fascia lata valves: a clinicopathological study. Sixteen frame-mounted fascia lata valves removed from the mitral, aortic or-in one patient-pulmonary position have been detailed histologically. These valves had remained in 15 patients $(11$ men and four women) for periods varying between 10 and 44 months. The reason for the original transplantation was either chronic rheumatic endocarditis or calcific aortic disease.

In the mitral position, the leaflet in position nearest the site of the original anterior mitral valve cusp showed the least changes. The remaining two leaflets of the fascia lata valve in the mitral position, as well as those removed from the aortic or pulmonary position, showed more severe changes; these consisted of degeneration of collagen tissue and often a severe decrease of nuclei belonging to the fibroblastic series. These changes, as well as superimposition of fibrin or fibrous tissue, tended to become more pronounced the longer the valve had remained in the patient.

Viability studies in valves removed from two patients have also been undertaken, showing very greatly reduced activity.

The possible causes for valve dysfunction have been reviewed, and the findings in this study suggest that contraction of fibrous tissue, which sandwiches the fascia lata valve cusps, may contribute to failure of satisfactory valve function. It is concluded that fascia lata forms a poor substitute for replacement of diseased cardiac valves.
\end{abstract}

In the search for an ideal substitute to replace diseased human valves, fascia lata has been employed. Reports using such tissue, either mounted on a frame or unmounted, in the aortic position, with satisfactory long-term function, have appeared in the literature (Senning, 1967; Ionescu et al., 1972).

Frame-mounted fascia lata substitute valves (Ionescu and Ross, 1969) have also been used in the mitral and tricuspid positions, in which shortterm follow-up has shown promising results. It soon became evident, however, that in the tricuspid area fascia lata valves were unsatisfactory (Edwards, 1972; Ross, Gonzalez-Lavin, and Dalichau, 1972). Longer periods of follow-up of patients showed an increasing number of failures of valve function in the mitral position also, using either supported or unsupported fascia lata valves (Cooper, 1972; Edwards, 1972;
Rabago, 1972; Ross et al., 1972). Even in the aortic position, evidence is now accumulating that failure of satisfactory valve function does eventually take place in a considerable number patients (Senning and Rothlin, 1973).

Between April 1969 and October 1970, 262 suß̧ ported fascia lata valves were implanted in 20 patients at the National Heart Hospital. Tht paper describes the histological features observed in 16 valves. Relevant clinical details are give and viability was studied in two valves.

\section{MATERIAL AND METHODS}

Sixteen valves from 15 patients, 11 men (a) range 22-57) and four women (age range 34-49\%, were available for study. Fascia lata was obtaineg fresh at the time of surgical operation for valve replacement. 
Viability studies were carried out on two valves. This was assessed quantitatively using auto radiography and the utilization of methyltritiated thymidine (Al-Janabi et al., 1972). After placing strips of fascia lata in nutrient medium $(199+10 \%$ calf serum), $5 \%$ methyl-tritiated thymidine was added. Tissue was incubated for 48 hours at $37^{\circ} \mathrm{C}$. Thin sections were cut and layered with a film of Ilford K2 nuclear emulsion (Kopriwa and Leblond, 1962). After drying and an interval of seven days at $4^{\circ} \mathrm{C}$ in light-proof boxes, viability was assessed by light microscopy.

After the removal of the material necessary for viability studies, the remaining tissue was placed in $15 \%$ formol saline. Subsequently, representative areas from each of the leaflets were chosen, blocked, and paraffin embedded, and 5 micron thick sections were stained with haematoxylin and eosin, Weigert's elastic van Gieson stain, and Alcian blue, where necessary. The results of the histological appearances were assessed subjectively.

\section{RESULTS}

The clinical details have keen summarized in Table I. The interval from the time of operation to clinically diagnosed dysfunction varied from immediately following operation to 41 months. The 16 valves had remained in patients before re-operation was undertaken for periods varying between 10 months and 44 months.
MACROSCOPIC APPEARANCE Uniform appearances of the fascia lata valves were found. None of the valve leaflets was normal. In those removed from the mitral area, the leaflet nearest to the position of the normal anterior mitral valve leaflet (that is, close to the left ventricular outflow tract and aortic valve) was only minimally affected in two patients and moderately severely affected in the remainder. The remaining two leaflets were consistently more severely thickened and retracted (Fig. 1). Detachment from the supporting frame

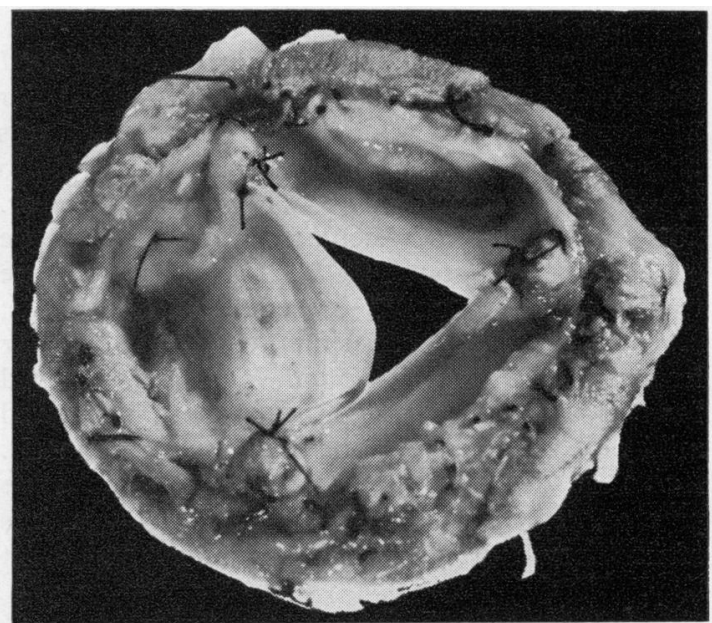

FIG. 1. Patient 2. Fascia lata mounted valve removed from the mitral position. 'Anterior' leaflet is seen on the left side of the photograph. The valve had remained in the patient for 33 months.

T A B L E I

FASCIA LATA GRAFT FAILURE IN 15 PATIENTS

\begin{tabular}{|c|c|c|c|c|c|c|c|}
\hline No. & $\begin{array}{c}\text { Age at } \\
\text { Op. }\end{array}$ & Sex & Pre-op. Diagnosis & $\begin{array}{c}\text { Interval from } \\
\text { Operation } \\
\text { to Dysfunction } \\
\text { (mth) }\end{array}$ & Type of Dysfunction & $\begin{array}{c}\text { Time to } \\
\text { Re-operation } \\
\text { (mth) }\end{array}$ & $\begin{array}{l}\text { Type of Valve } \\
\text { Replacement }\end{array}$ \\
\hline $\begin{array}{l}1 \\
2 \\
3\end{array}$ & $\begin{array}{l}45 \\
49 \\
44\end{array}$ & $\begin{array}{l}\mathbf{F} \\
\mathbf{F} \\
\mathbf{M}\end{array}$ & $\begin{array}{l}\text { Mitral disease } \\
\text { Mitral disease } \\
\text { Mitral disease }\end{array}$ & $\begin{array}{r}7 \\
17 \\
32\end{array}$ & $\begin{array}{l}\text { Mitral insufficiency } \\
\text { Mitra! insufficiency } \\
\text { Mitral insufficiency }\end{array}$ & $\begin{array}{l}21 \\
33 \\
43\end{array}$ & $\begin{array}{l}\text { Mitral Starr } \\
\text { Mitral Starr } \\
\text { Mitral Braunwald- }\end{array}$ \\
\hline 4 & $27^{1}$ & $\mathbf{M}$ & $\begin{array}{l}\text { Insufficiency Pul- } \\
\text { monary autograft in } \\
\text { mitral position }\end{array}$ & 36 & $\begin{array}{l}\text { Mitral and aortic } \\
\text { insufficiency }\end{array}$ & 44 & $\begin{array}{l}\text { Cutter } \\
\text { Aortic and mitral Starr }\end{array}$ \\
\hline $\begin{array}{l}5 \\
6 \\
7 \\
8 \\
9\end{array}$ & $\begin{array}{l}36 \\
34 \\
30 \\
38 \\
44\end{array}$ & $\begin{array}{l}\mathbf{F} \\
\mathbf{F} \\
\mathbf{M} \\
\mathbf{M}\end{array}$ & $\begin{array}{l}\text { Aortic stenosis } \\
\text { Aortic disease } \\
\text { Aortic insufficiency } \\
\text { Aortic stenosis } \\
\text { Haemolysis in aortic } \\
\text { Starr valve }\end{array}$ & $\begin{array}{r}2 \\
0 \\
6 \\
0 \\
18\end{array}$ & $\begin{array}{l}\text { Aortic insufficiency } \\
\text { Aortic insufficiency } \\
\text { Aortic insufficiency } \\
\text { Aortic insufficiency } \\
\text { Aortic insufficiency }\end{array}$ & $\begin{array}{l}10 \\
16 \\
20 \\
20 \\
28\end{array}$ & $\begin{array}{l}\text { Aortic Starr } \\
\text { Aortic Starr } \\
\text { Fresh aortic homograft } \\
\text { Aortic homograft } \\
\text { Aortic Starr }\end{array}$ \\
\hline $\begin{array}{l}10 \\
11 \\
12 \\
13 \\
14 \\
15\end{array}$ & $\begin{array}{l}56 \\
52 \\
48 \\
28 \\
57 \\
27^{1}\end{array}$ & $\begin{array}{l}\mathbf{M} \\
\mathbf{M} \\
\mathbf{M} \\
\mathbf{M} \\
\mathbf{M} \\
\mathbf{M}\end{array}$ & $\begin{array}{l}\text { Aortic insufficiency } \\
\text { Aortic stenosis } \\
\text { Aortic disease } \\
\text { Aortic disease } \\
\text { Aortic stenosis } \\
\text { Insufficiency Aortic } \\
\text { homograft in aortic } \\
\text { position }\end{array}$ & $\begin{array}{l}32 \\
41 \\
39 \\
34 \\
33 \\
36\end{array}$ & $\begin{array}{l}\text { Aortic insufficiency } \\
\text { Aortic insufficiency } \\
\text { Aortic insuficiency } \\
\text { Aortic insufficiency } \\
\text { Aortic insufficiency } \\
\text { Mitral and aortic } \\
\text { insufficiency }\end{array}$ & $\begin{array}{l}35 \\
37 \\
40 \\
41 \\
43 \\
44\end{array}$ & $\begin{array}{l}\text { Aortic Starr } \\
\text { Aortic Starr } \\
\text { Fresh aortic homograft } \\
\text { Pulmonary autograft } \\
\text { Aortic Starr } \\
\text { Aortic and mitral Starr }\end{array}$ \\
\hline 16 & 22 & $\mathbf{M}$ & $\begin{array}{l}\text { Repl. of normal } \\
\text { pulmonary valve }\end{array}$ & 17 & Pulmonary stenosis & 24 & $\begin{array}{l}\text { Pulmonary fresh } \\
\text { homograft }\end{array}$ \\
\hline
\end{tabular}

Same patient. 
or at the 'commissure' was not noted. Suture material was invariably covered by endothelium extending from the left atrium.

In the valves removed from the aortic position, the three leaflets were uniformly affected. Thickening and retraction was usual. The valve removed from the pulmonary position showed similar changes to those removed from the aortic site.

HISTOLOGICAL APPEARANCES These have been summarized in Table II.

\section{Mitral position}

1. The anterior ('aortic') valve leaflet in patient 1 (Table II), having survived in the patient for 21 months, showed minimal increase of thickness only and a normal number of nuclei belonging to the fibroblastic series. The nuclei were, however, not fusiform nor vesicular but tended to be round and pyknotic (Fig. 2). The collagen tissue was normally arranged in regular, wavy bands; recent fibrin was superimposed. The anterior leaflets of patients 2,3 , and 4 (having survived for periods varying from 33 to 44 months) showed mild or considerably more thickening (Table II). Areas of degeneration of collagen tissue were present, consisting of an eosinophilic change, loss of fibrillary character, and irregular arrangement of the degenerated fibres (Fig. 3). In these areas there was a patchy absence of nuclei, confined to the inner layers of the leaflet in one, and more widespread in the other two anterior valve leaflets.

2. The other two leaflets of patients 1,2,3, ant 4 , in the mitral position, showed increasing thick= ness as well as degeneration of collagen tissuej and virtual absence of nuclei in the valves having survived for 43 and 44 months respectively Fibrous tissue was superimposed, which wis minimal in two and mild in the remaining two cases (Fig. 4). The distribution of this tissue was often patchy. The length of time the valves halp remained in the patient did not affect the thick ness or the extent of this superimposed fibrous tissue. Changes of degeneration were severe in those valves having survived 43 and 44 month respectively.

Aortic position In the aortic position, thicknes did not depend on the length of time the valvot had survived in the patient. Degenerative changes tended to increase with survival in the patien? with a concomitant decrease of nuclei (except i case 14). If severe, regular arrangement of collagen tissue was lost. Spaces resembling fâे were occasionally observed. The covering by fibrous tissue or fibrin was variable.

T A B L E I I

\begin{tabular}{|c|c|c|c|c|c|c|}
\hline No. & $\begin{array}{c}\text { Time to } \\
\text { Re-operation (mth) }\end{array}$ & $\begin{array}{l}\text { Increase in } \\
\text { Thickness }\end{array}$ & $\begin{array}{l}\text { Reduction of } \\
\text { Nuclei }\end{array}$ & Degeneration & Fibrin & $\begin{array}{l}\text { Fibrous } \\
\text { Tissue }\end{array}$ \\
\hline $\begin{array}{c}\text { Aortic } \\
1 \\
2 \\
3 \\
4\end{array}$ & $\begin{array}{c}\text { Mitral Valve Leaflets } \\
21 \\
33 \\
43 \\
44\end{array}$ & $\begin{array}{l} \pm \\
+ \\
+++ \\
+++\end{array}$ & $\begin{array}{l}\text { Nil } \\
\left.+ \text { (inner } \frac{1}{3}\right) \\
+++ \\
+++\end{array}$ & $\begin{array}{l}\bar{z} \\
\pm++ \\
+++\end{array}$ & $\begin{array}{l}+ \\
+ \\
+\end{array}$ & $\begin{array}{l}\dot{ \pm} \\
\dot{ \pm} \\
+ \\
+\end{array}$ \\
\hline $\begin{array}{r}\text { Other } \\
1 \\
2 \\
3 \\
4\end{array}$ & eaflets in Mitral Position & $\begin{array}{l}++ \\
++ \\
++ \\
+++\end{array}$ & $\begin{array}{l}+ \text { (patchy) } \\
+++ \text { (patchy) } \\
\text { Absent } \\
\text { Absent }\end{array}$ & $\begin{array}{l}\text { 去 } \\
+++ \\
+++\end{array}$ & $\begin{array}{l}+ \\
\pm \\
+ \\
+\end{array}$ & $\begin{array}{l} \pm \\
+ \\
\pm \\
+\end{array}$ \\
\hline $\begin{array}{r}\text { Aortic } \\
5\end{array}$ & Position & +++ & +++ (inner $\left.\frac{1}{3}\right)$ & $+++\left(\right.$ inner $\left.\frac{1}{\jmath}\right)$ & +++ & \pm \\
\hline $\begin{array}{r}6 \\
7 \\
8 \\
9 \\
10 \\
11 \\
12 \\
13 \\
14 \\
15\end{array}$ & $\begin{array}{l}16 \\
20 \\
20 \\
28 \\
35 \\
37 \\
40 \\
41 \\
43 \\
44\end{array}$ & $\begin{array}{l}++ \\
+ \\
+++ \\
++ \\
+ \\
+ \\
++ \\
++ \\
+ \\
++\end{array}$ & $\begin{array}{l}+ \text { (Patchy) } \\
+ \text { (Patchy) } \\
\text { Absent } \\
\pm+++++(\text { tip) } \\
+++++ \\
+ \text { Absent } \\
\text { Absent } \\
\text { Absent } \\
\left.+++ \text { (inner } \frac{1}{\text { ) }}\right) \\
\text { Absent }\end{array}$ & $\begin{array}{l}+++ \text { (fat vacuoles) } \\
+ \text { (patchy) } \\
+++ \\
++ \\
++ \text { (fat) } \\
+++ \\
+++ \\
+++ \\
+ \text { (focal) } \\
++++\end{array}$ & $\begin{array}{l} \pm(1 \text { area only }) \\
+ \\
\pm \\
\pm \\
\pm \\
\pm \\
\frac{ \pm}{+}++\end{array}$ & $\begin{array}{l} \pm(1 \text { area only } \\
\pm \\
+ \\
+ \\
+ \\
+ \\
\pm \\
+\end{array}$ \\
\hline $\begin{array}{c}\begin{array}{c}\text { Pulmon } \\
16\end{array} \\
\end{array}$ & ary & + & Absent & ++++ & + & + \\
\hline $\begin{array}{r}\text { Viabilit } \\
14 \\
14\end{array}$ & $\begin{array}{l}\text { Studies } \\
\text { Low (excluding ao } \\
\text { Very low }\end{array}$ & alve) & & & & \\
\hline
\end{tabular}




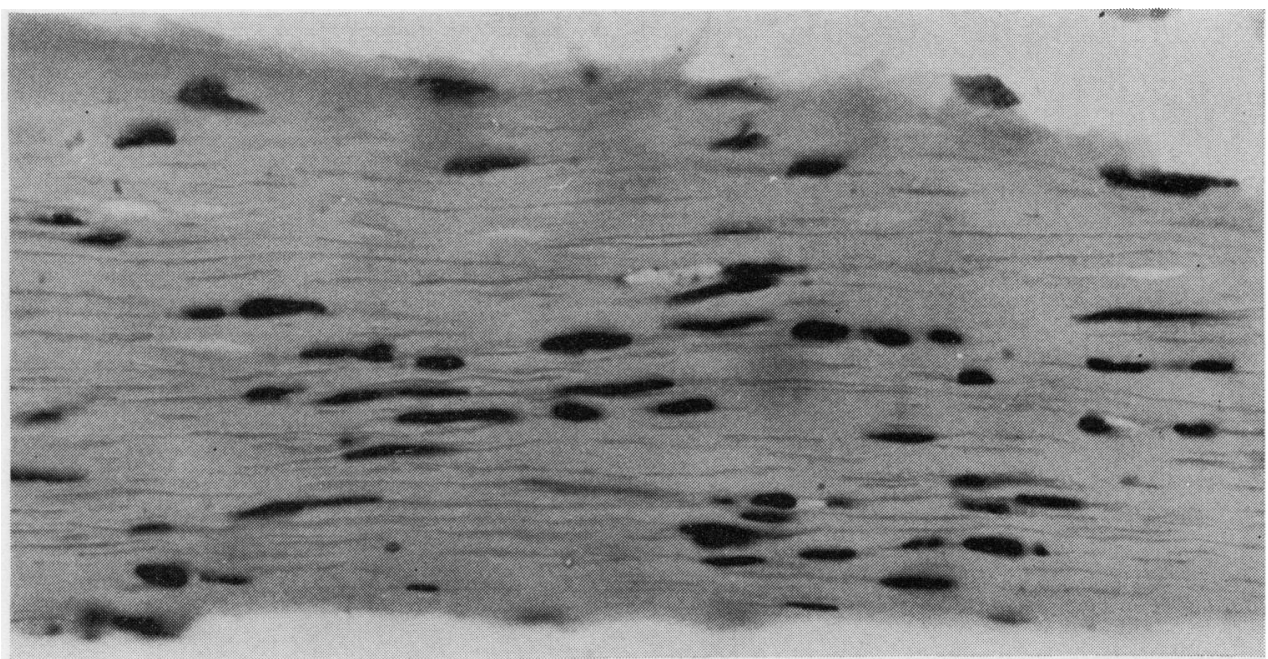

FIG. 2. Patient 1. Photomicrograph of fascia lata removed from the mitral position (anterior leaflet), showing normally arranged collagen fibres, but the nuclei are pyknotic and rounded and only a few fusiform shaped nuclei can be observed (Haematoxylin and eosin $\times 665)$.

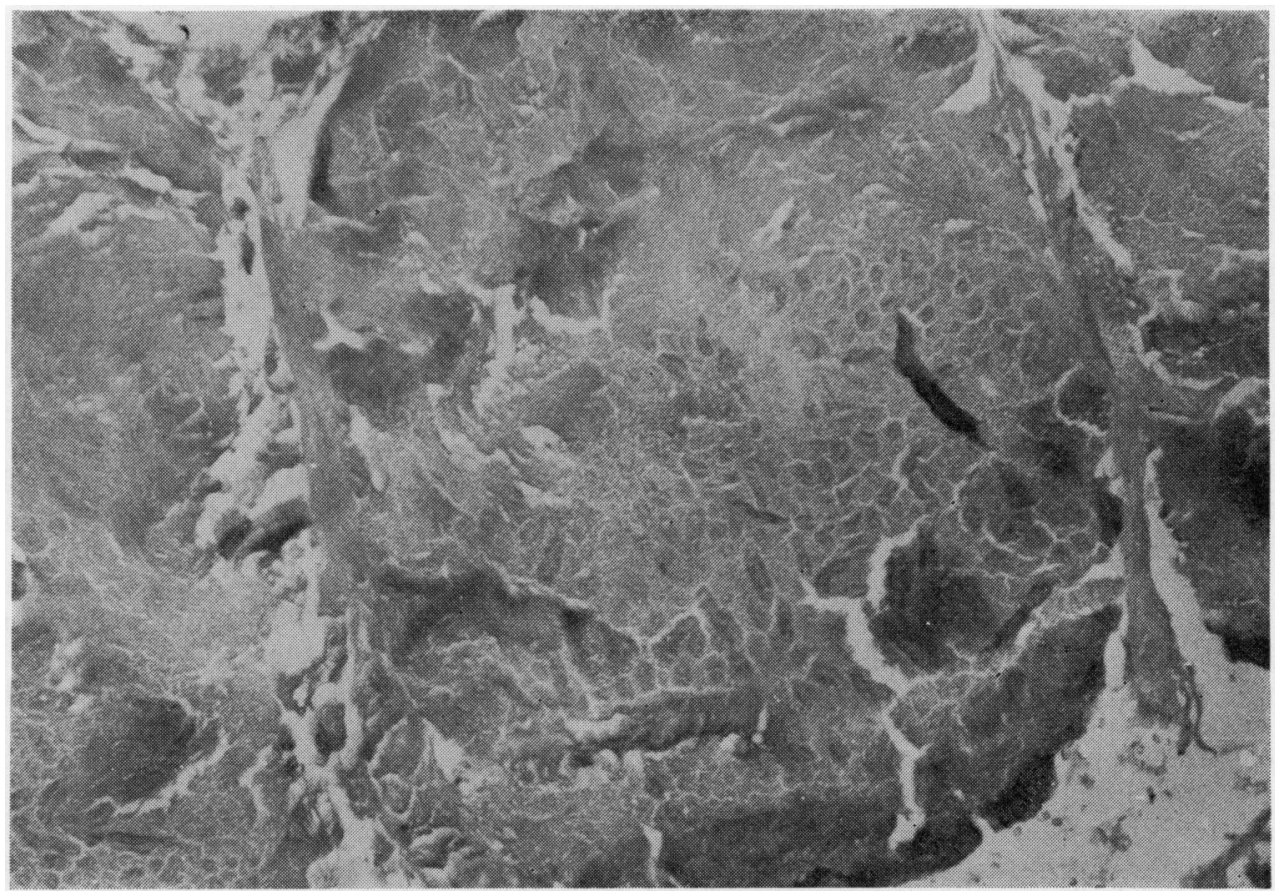

FIG. 3. Photomicrograph of a degenerated area of fascia lata, showing loss of the regular fibrillar character of fascia lata and also absence of nuclei. The darker areas represent eosinophilic change ( $H$ and $E \times 135)$. 


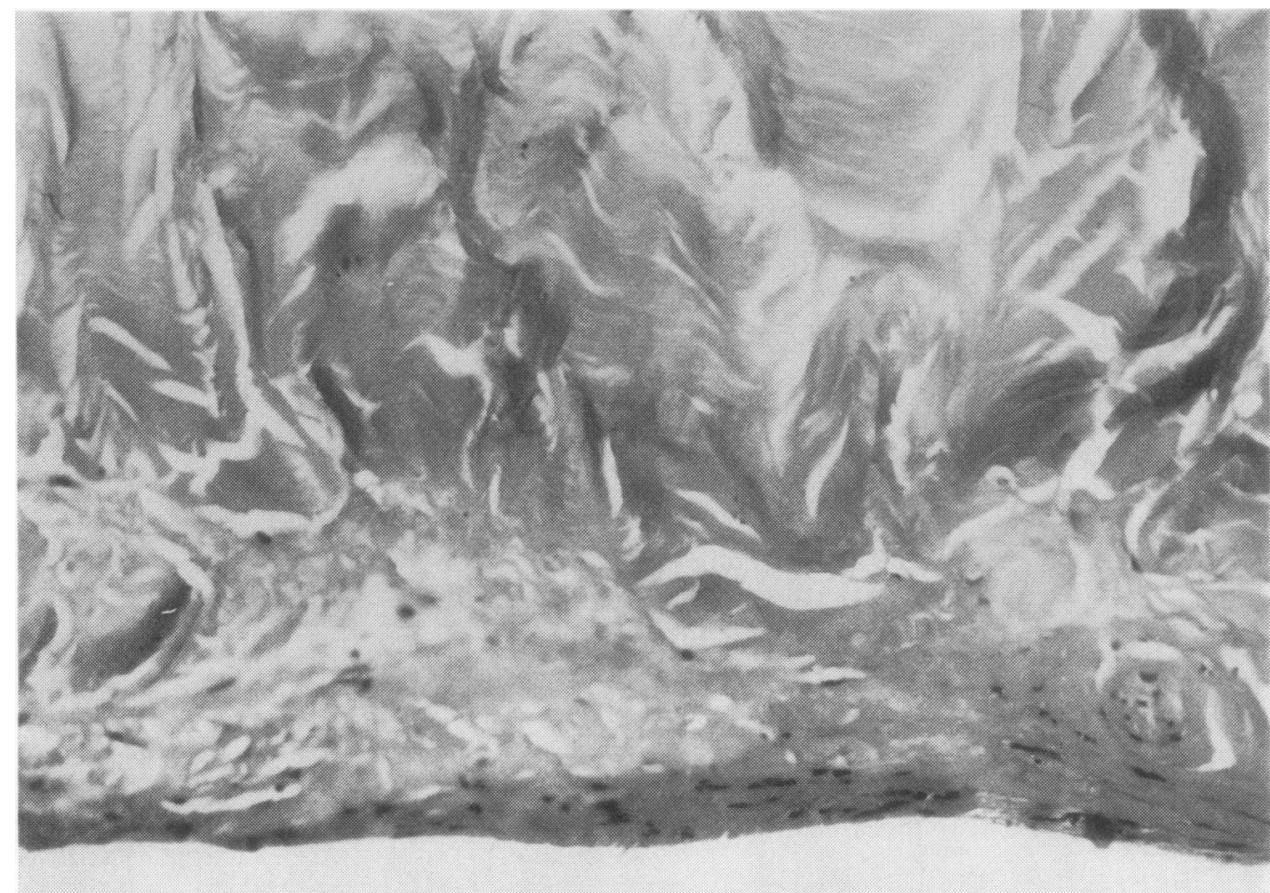

FIG. 4. Photomicrograph of a fascia lata valve removed from the mitral position 33 months after transplantation. Note the degenerative changes in the centre and the superimposition of collagen tissue showing the normal complement of nuclei $(H$ and $E \times 135)$.

Pulmonary position In the pulmonary position there was slight thickening of fascia lata only, with a total absence of nuclei and severe degeneration. Fibrous tissue and fibrin were superimposed.

Viability studies in two valves have been carried out. Thymidine uptake is considered a good index for viability of cells, representing active cell metabolism. The results have been added to Table II. In the two cases studied, low viability or very low viability was recorded (patients 1 (excluding aortic leaflet) and 14 (Table II)).

\section{DISCUSSION}

The use of cardiac valves fashioned from fascia lata approached the ideal situation for a substitute valve. The criteria for such an ideal substitute were summarized by Ross (1970) as follows: 'Non-obstructive central flow orifice, freedom from embolism, biological tissue, living tissue, autogenous material, and availability in a variety of sizes.' Follow-up of many patients has shown, however, that changes do take place in the fascial tissue requiring eventual re-operation, so that the initial high hopes for using fascia lata have not been realized.

The macroscopic appearances of these valves show thickening and retraction of the valve leaflets, but often the least involved is the 'anterior' leaflet of the fascia lata valve in the mitral position (that is, the leaflet immediately adjacent to the left ventricular outflow tract and aortic valve). Similar appearances have been re을 ported by Rabago (1972) and McEnany, Ross? and Yates (1972). The remaining two leaflets ire. the mitral position show more severe changes. Irf the fascia lata valves removed from the aortic position, equal involvement of all leaflets wa found; this also applied to the valve removedo from the pulmonary site.

Histologically, with the exception of the leaflets in the 'anterior mitral position' which showed the best preservation of the original fascial tissue? increasing degeneration and absence of nucleic tended to depend on the length of time the sub $\frac{\vec{D}}{\mathrm{D}}$ stitute valve had survived in the patient. If patchy? these degenerative changes were usually seen in the inner layers of the removed valve tissue (the original fascia lata); the outer surfaces showedo 
varying degrees of fibrous tissue superimposition with a normal component of nuclei belonging to the fibroblastic series, often most prominent at the base of the leaflet. Not infrequently, superimposition of fresh fibrin was also evident. This sandwich effect could easily be identified and tended to be more prominent the longer the valve had survived in the patient. Bernhard et al. (1973) followed the morphological changes in fascia lata mitral valves up to 10 months following transplantation, and they observed preservation of collagen tissue but disappearance of the fibrocytes after six months' survival in patients. Our earliest removed valve in this series had survived for 10 months and showed severe decrease of the inner third of nuclei, considerable superimposition of fibrin, and little fibrous tissue. Senning and Rothlin (1973) observed fibrin in the first few postoperative days. It is well known that fibrin becomes organized into fibrous tissue and, as this tissue contracts, the thickening contributes to the distortion observed in many of the surgically removed valve leaflets. Other possible mechanisms of failure of satisfactory valve function include irregular mechanical stimulation of the threeleaflet fascia lata valve in the mitral position and inherent deficiency in fascial strength (McEnany et al., 1972), making such a valve unsuitable for implantation in the mitral position. Talavlikar, Walbaum, and Kitchin (1973) have found that valve failure is less common when the design is modified to provide loose cusp structures. These workers suggest that accelerated haemodynamic stress rather than inevitable degeneration appears to be the more likely explanation of valve failure. Even slightly irregular suturing, or placing sutures too tightly on the frame-mounted valve leaflets, would accelerate valve failure. Repetitive trauma and failure to consider shrinkage of fascia lata, estimated to be in the region of $30 \%$, has been suggested as a cause of valve dysfunction by Bailey et al. (1973). These authors consider fascia lata to be the best available autologous tissue. In their experience, macroscopical and microscopical appearances were unchanged for periods of five or more years. These findings differ from those presented in this study; they also differ from the observations made by other workers who have studied the removed valves pathologically.

Our viability studies in two cases have shown patchy survival of tissue for 21 months and 43 months respectively. Although the number studied is small, it does indicate that some tissue does survive for a considerable period of time.
Comparison of prosthetic valves and homografts with fascia lata valve substitutes has shown an overall poorer result with the latter (Edwards, 1972). Fascia lata valves in the aortic position had the best functional record, but there is evidence now accumulating from long-term follow-up that valve failure, as well as infective endocarditis, may occur in the aortic position (Senning and Rothlin, 1973). Our results confirm these findings.

There is evidence to suggest that, apart from other possible causes of valve failure, the superimposed fibrin, when it becomes organized into fibrous tissue and subsequently contracts, contributes to valve dysfunction. The evidence also suggests that long-term survival of autogenous fascia lata is poor and that it is an unsatisfactory substitute for the replacement of diseased cardiac valves.

\section{REFERENCES}

Al-Janabi, N., Gonzalez-Lavin, L., Neirotti, R., and Ross, D. N. (1972). Viability of fresh aortic homograft; a quantitative assessment. Thorax, 27, 83.

Bailey, C. P., Hirose, T. T., Folk, F. S., and Hastanan, S. (1973). Mitral reconstruction with commissural cusp of fascia lata. New York State Journal of Medicine, 2, 2677.

Bernhard, A., Thiede, A., Müller-Hermelink, H. K., Krug, A., Fischer, K., and Yankah, A. C. (1973). Mitral valve replacement with autologous fascia lata; Results of morphologic examinations. Journal of Thoracic and Cardiovascular Surgery, 65, 94.

Cooper, E. (1972). Aortic and mitral valve replacement with autologous fascia lata valves. Medical Journal of Australia, 2, Suppl. (August), p. 47.

Edwards, W. S. (1972). Late results with autogenous tissue heart valves. Journal of Cardiovascular Surgery, 13, 276.

Ionescu, M. I., Pakrashi, B. C., Holden, M. P., Mary, D. A., and Wooler, G. H. (1972). Results of aortic valve replacement with frame-supported fascia lata and pericardial grafts. Journal of Thoracic and Cardiovascular Surgery, 64, 340.

- and Ross, D. N. (1969). Heart-valve replacement with autologous fascia lata. Lancet, $2,335$.

Kopriwa, B. M. and Leblond, C. P. (1962). Improvements in the coating technique of radioautography. Journal of Histochemistry and Cytochemistry, 10, 269.

McEnany, M. T., Ross, D. N., and Yates, A. K. (1972). Valve failure in seventy-two frame-supported autologous fascia lata mitral valves. Journal of Thoracic and Cardiovascular Surgery, 63, 199.

Rabago, G. (1972). Early and late results with fascia lata valves in aortic and mitral position. Journal of Cardiovascular Surgery, 13, 296. 
Ross, D. N. (1970). Fascia lata replacement of the heart valves. Proceedings of the Royal Society of Medicine, 63, 946.

Gonzalez-Lavin, L., and Dalichau, H. (1972). A two-year experience with supported autologous fascia lata for heart valve replacement. Annals of Thoracic Surgery, 13, 97.

Senning, A. (1967). Fascia lata replacement of aortic valves. Journal of Thoracic and Cardiovascular Surgery, 54, 465.

and Rothlin, M. (1973). Reconstruction of the aortic valve with fascia lata; initial and long term results. Clinical experience. Vascular Sur gery, 7, 29.

Talavlikar, P. H., Walbaum, P. R., and Kitchin, A. H (1973). Haemodynamic results of replacement of mitral and aortic valves with autologous fascia lata prostheses. Thorax, 28, 169.

Requests for reprints to: Dr. E. G. J. Olsen, Depart $\overrightarrow{\vec{w}}$ ment of Morbid Anatomy and Histopathology, National Heart Hospital, Westmoreland Street, London W1M 8BA. 